\title{
Increasing Growth and Production on Two Rice Varieties of Submersion Stress Condition on Two Lowland Swamp Types
}

\author{
Gribaldi
}

Agrotechnology Study Program Faculty of Agriculture, University of Baturaja, Jl. RatuPenghulu No. 02301 Karang Sari

Baturaja 32115, South Sumatra, Indonesia.

\begin{abstract}
This study aims to determine the best fertilizer treatment at vegetative stage for the growth and yield of rice submergence stress conditions on two types of swampy lowland. The experimental design used in this research was spilt-plot design with three replications. The main plot was fertilization treatment consisting of $P 1=$ base fertilization, $P 2=$ fertilizer before being submerged, $P 3=$ fertilizer after being submerged + PPC Micro, P4 = fertilization before and after being submerged. The subplots are varieties of rice, $V 1=$ Inpara 5, V2 = IR 64. The subplot was rice variety which consisted of V1 = Inpara 5, V2 =IR 64. The results showed fertilization treatment can increase rice production growth and submergence stress conditions, varieties of Inpara 5 added with fertilization before flooded can suppress a decrease in grain yield for $16 \%$ in the shallow-back swamp and $6 \%$ in middle-back swamps or with each production of 2.9 and 5.1 tons per hectare, varieties of Inpara 5 which is giving fertilization before flooded, tends to be a good treatment to be developed in rice submergence cultivation both in the the shallow-back swamp and middle-back swamps.
\end{abstract}

Keywords- Fertilization, Submergence stress, Rice varieties, Lowland Swamp.

\section{INTRODUCTION}

The production of the cultivation of rice (Oryza Sativa L.) needs to be developed from year by year based on the growth of people's composition. The growth of production can be done by the repairing of productivity in the regions that affected in the submersion in which become the main problem in the cultivation of the rice. The wide area of the rice planting that affected the gripping of submersion because of the flood is seen perfectly increasing. This is rooted by the flowing of the rain and the increasing of the water flooding because of the global warming [3]. The remains that caused the gripping toward the rice in the areas of South Asia and Southern Asia is seen 15 million hectare every year [4], meanwhile in South Sumatera the wide of the rice that easily affected the flood is about 124.465 ha
[2]. Besides, the potential of the areal that comes in a problem, i.e., the gripping of the submersion to be developed into the field of agriculture is very large, especially in the area of lowland swamps. According to [10], the potential of lowland swamp area in Indonesia that can be developed into the field of agriculture is about 13 million has, meanwhile in South Sumatera is seen about 2,0 million ha [13]

The main problem that is faced in the operation of the agriculture cultivation in the field of lowland area is the case of the submersion that limits the growth and production of the plant. Besides, the $\mathrm{pH}$ of the soil and KTK, also the content of the low element of substance, e.g. N, P, and K [9]. Besides, the farmers in lowland swamps still find the difficulties in predicting the high amount of water puddle, so that they faced the risk of the submersion of rice planting at the phase of vegetative growth.

The decreasing of the submerged rice crops at the furrows/varieties that contained $S u b-1$ gene less than the contrast of the decreasing of the crops of varieties without Sub-1 gene. The decreasing of the crop in variety of IR 64 Sub-1 is $16 \%$ while the variety of IR 64 without Sub-1 gene the decreasing of crops reaches $39 \%$ [7]. According to [1], the lost of rice crops reaches $30 \%$ because of the submersion, whenever it can be ceased into the less of $10 \%$ through the agronomic treatment that means bigger for the farmers and the increasing of the productivity of national rice.

By knowing that the wide are that is oftentimes submerged because of the flood is seen more large, hence the founding of technology through this study will be more beneficial in the increasing of the productivity of rice in lowland swamps in term of enhancing the endurance of national food.

\section{MATERIALS AND METHODS}

\subsection{Experiment site}

This study was conducted in two locations, i.e., shallowback swamp and middle-back swamp areas at Kebun Percobaan Padi Rawa Lebak BPTP South Sumatera in Kayu Agung, Ogan Komering Ilir (OKI) sub district. 


\subsection{Experiment design}

This study used the split plot design with three repetitions. The main plot was fertilization treatment consisting of P1 $=$ base fertilization, $\mathrm{P} 2=$ fertilizer before being submerged, P3 = fertilizer after being submerged + PPC Micro, P4 = fertilization before and after being submerged. The subplot was rice variety which consisted of $\mathrm{V}_{1}=$ Inpara $5, \mathrm{~V} 2=\mathrm{IR} 64$.

\subsection{Implementation of field research}

The shallow-back swamp and middle-back swamp were used as the study plot. This area was then cleared and divider ridge was improved. Installation of the plastic wall with $1 \mathrm{~m}$ height as the divider of study plot was conducted during land preparation.

The germs of Inpara 5 variety and IR 64 rice was firstly submerged along 24 hours, then it was incubated for 48 hours, after it germinating was seeded at particular place that have been prepared. After more than at least 2 weeks, the germs was moved and kept at its place whose size was $1.2 \mathrm{~m} \times 8 \mathrm{~m}$ for about 10 days, by relating that the height of the water was still in a high quantity so that the germs were re-moved and kept for 10 days at the fields' bund. After the germs were moved from its place to every plot sides (units) of trial whose size was $1,5 \mathrm{~m} \times 2 \mathrm{~m}$ after the height of the water was in the rice field for about $5-10 \mathrm{~cm}$, by withdrawing from its seedbed and was planted in the position of standing in which the space of planting was 25 $\mathrm{cm} \times 25 \mathrm{~cm}$, and used 2-3 seeds per $2 \mathrm{~cm}$ holes.

The basic fertilizing was done when the planting with fertilizing dosage for one hectare was Urea $100 \mathrm{Kg}$, SP36 $128 \mathrm{Kg}$, and $\mathrm{KC} 1100 \mathrm{Kg}$. At that treatment of fertilizing before the submersion, the dosage used for 1 hectare was Urea $50 \mathrm{Kg}$, TSP $100 \mathrm{Kg}$, and $\mathrm{KC} 1100 \mathrm{Kg}$ when the planting, the remnant urea of $50 \mathrm{Kg}$ was given at the age of 42 hst. The fertilizing after submersion, with the dosage N, $\mathrm{P}$, and $\mathrm{K}$ for each 50,30 , and $30\left(\mathrm{Kg} \mathrm{ha}^{-1}\right)$, by spreading to the inside of the plot treatment whose size was $6 \times 8 \mathrm{~m}$, meanwhile for the PPC micro $2 \mathrm{ml} / 1$ water, by spraying to the plants, its giving was done for 7 days after submersion. The fertilizing treatment before and after submersion were the combination of both treatments.

The seeds of rice that have reached the age of 7 HST was done the submersion by putting the water into the plots whether through the rising water or by using the pump of the close well from the plots. The duration of the submersion was 7 days that belonged to the height of water that have reached the crown of the plant. The caring includes the activity to maintain the high submersion of water at the minimum quantity of $15 \mathrm{~cm}$ from the crown until the treatment, by putting the water to the plots through the pump frequently.

\subsection{Yield and observation}

Observation of agronomical characteristics were consisted of percentage of survive plant $(\%)$, plant height $(\mathrm{cm})$, number of productive tillers numbers per clump, plant dry matter weight per clump (g) and grain yield per clump (g). Yield components were consisted of number of grains per panicle (grains), percentage of filled grains per panicle $(\%)$ and 100 grain weight $(\mathrm{g})$.

\subsection{Statistical analysis}

Mean values were calculated for each of the measured variables, and ANOVA was used to assess the treatment effects. Data were processed using SAS program Portable 9.1.3 for the $\mathrm{F}$ test.

\section{RESULTS AND DISCUSSION}

Results of variance analysis (Table 1) showed that every altering among varieties influences obviously except at the altering for the height of the plants, the amount of productive offspring and the weight of 100 grains of rice for the shallow-back swamp, meanwhile the middle-back swamp toward the altering, Plant height and weight of 100 grains of rice. Next, for each of the altering among the treatment influences obviously except at the altering, the height of plants, percentage of spirited rice, the amount of rice per malai and the weight of 100 grains of rice to the shallow-back swamp, meanwhile middle-back swamp toward the altering of the plant height, the weight of dried plants, the amount of rice per malai, percentage of spirited rice and the weight of 100 grains of rice. The interaction among the varieties and the treatment of fertilizing influences not obviously, except at the altering of the weight of dried plants at shallow-back swamp, meanwhile middle-back swamp toward the altering the percentage of live plants and weight of dried plants.

Table.1: The result of analyzing the diversity of influence to various fertilizing at two varieties of rice to the altering observed

\begin{tabular}{lccccccc}
\hline Altering Observed & \multicolumn{3}{c}{ Shallow-back swamp } & \multicolumn{3}{c}{ Middle-back swamp } \\
\cline { 2 - 7 } & $\mathrm{V}$ & $\mathrm{F}$ & $\mathrm{V} x \mathrm{~F}$ & $\mathrm{~V}$ & $\mathrm{~F}$ & $\mathrm{VxF}$ \\
\hline Percentage of Survive Plant & $*$ & $*$ & $\mathrm{~ns}$ & $*$ & $*$ & $*$ \\
Plant height & $\mathrm{ns}$ & $\mathrm{ns}$ & $\mathrm{ns}$ & $\mathrm{ns}$ & $\mathrm{ns}$ & $\mathrm{ns}$ \\
Number of productive tillers & $\mathrm{ns}$ & $*$ & $\mathrm{~ns}$ & $*$ & $*$ & $\mathrm{~ns}$
\end{tabular}


Plant dry matter weight

Percentage of filled grains per panicle

Number of grains per panicle

100 grains weight

Grain yield per plot converted into yield per hectare

$\begin{array}{ccc}* & * & * \\ * & \mathrm{~ns} & \mathrm{n} \\ * & \mathrm{~ns} & \mathrm{n} \\ \mathrm{ns} & \mathrm{ns} & \mathrm{n} \\ * & * & \mathrm{n}\end{array}$

ISSN: 2456-1878

Notes : V= Variety; $\mathrm{F}=$ Fertilization; * = significant effect; $\mathrm{ns}=$ no significant effect

\subsection{Percentage of Survive Plant In condition of} the submersion gripping, the influence of treatment of fertilizing influence toward the percentage of survives plants from two varieties of rice that were tested in two lowland swamps fields (Table 2). The Inpara 5 variety produced the average percentage of live plants that were higher than the variety of IR 64 at all fertilizing treatment. This showed that repaired power of variety of Inpara 5 (V2) were higher than the variety of IR 64. The capability of restoration highly depended on the capability of plants to adapted fast to the condition after experiencing the submersion gripping. According to [1], the live powers of plants were also influenced by aerobic shock when the plants did not submerge. The change of concentration of antioxidant and enzymes like superoxide dismutase (SOD) in rice cultivars that were submersion tolerant to produce protection systems toward the air after exporting the surrounding of hypo sic or agnostic. Next, the fertilizing treatment before and/or after being submerged can enhance the percentage of live plants. This is seen as the setting of fertilizer giving before and/or after being submerged can enhance the plants' vigor, so that it can enhance the percentage of survives plants. According to [11], the extending of fertilizer, especially nitrogen before and after being submerged was very influential toward the germs vigor.

Table.2: Percentage of survive plants (\%) of two varieties of rice at some treatments of fertilizing in the condition of the submersion gripping at various lowland swamps

\begin{tabular}{lllllllllll}
\hline \multirow{2}{*}{ Vari } & \multicolumn{4}{c}{ Shallow-back swamp } & \multicolumn{5}{c}{ Middle-back swamp } \\
\cline { 2 - 11 } eties & P0 & P1 & P2 & P3 & P4 & P0 & P1 & P2 & P3 & P4 \\
\hline Inpara 5 & 100 & 84.6 & 92.0 & 86.0 & 89.0 & 100 & 75 & 96 & 97 & 88 \\
IR 64 & 100 & 72.5 & 76.2 & 72.4 & 75.0 & 100 & 29 & 83 & 87 & 71
\end{tabular}

Notes: P0: Basic fertilizing without submersion, P1: Basic fertilizing, P2: Fertilizing before being submerged, P3: Fertilizing after being submerged, P4: Fertilizing before and after being submerged.

Percentage of survive plant for IR 64 rice variety which experienced two times submergence tend to be lower than that of one time submergence (Table 3), whereas Inpara 5 rice variety still had high percentage of survive plant although experienced two times submergence. This fact showed that Inpara 5 rice variety (V2) had higher recovery capacity than that of other variety.

\subsection{Plant height}

The height of two varieties of rice that were given the treatment in the condition of submersion gripping indicated that the various responds, yet the extending of fertilizer before being submerged was higher than another fertilizing treatment (Table 3). Varieties IR 64 (V2) with the extending of fertilizing treatment before being submerged (P2) at shallow-back swamp had the highest plant height, that was $81.1 \mathrm{~cm}$ meanwhile at the middle-back swamp, the variety Inpara 5 (V1) with the extending of fertilizing treatment before being submerged (P2) had the highest plant height, that was $85 \mathrm{~cm}$.

Table 3.Plant height (cm) of two varieties of rice at some treatments of fertilizing in the condition of submersion gripping at various Lowland Swamp

\begin{tabular}{lllllllllll}
\hline \multirow{2}{*}{ Vari } & \multicolumn{4}{c}{ Shallow-back swamp } & \multicolumn{5}{c}{ Middle-back swamp } \\
\cline { 2 - 11 } eties & P0 & P1 & P2 & P3 & P4 & P0 & P1 & P2 & P3 & P4 \\
\hline Inpara 5 & 74.7 & 72.1 & 80.7 & 72.7 & 71.8 & 77 & 80 & 85 & 78 & 79 \\
IR 64 & 79.5 & 74.9 & 81.1 & 77.0 & 70.3 & 74 & 83 & 83 & 79 & 81 \\
\hline
\end{tabular}

Notes: P0: Basic fertilizing without submersion, P1: Basic submersion, P2: Fertilizing before being submerged, P3: Fertilizing after being submerged, P4: Fertilizing before and after being submerged. 
This was be caused of the extending of fertilizing before and/or after being submerged can provide enough nutrition to the next growth, after having the condition of fertilizer gripping at the both types of valley field. According to [12], treatment of the extending of fertilizer setting, especially nitrogen will give the influence toward plant height and the increasing of the rice height. Besides, according to [5], plant height after the period of the submersion gripping was perfectly influenced by the variety of rice rather than the fertilizing treatment.

\subsection{Number of productive tillers}

Number of productive tillers at two varieties of rice with the giving of fertilizing treatment for the second types of lowland swamp field (Table 4). Variety IR 64 (V2) that was given fertilizing treatment after being submerged (P3) had the highest number of productive tillers, that was 12.9 steam at the shallow-backswamp , meanwhile at the middleback swamp, variety of IR 64 that was given the fertilizing treatment before being submerged (P2) had the highest number of productive tillers, that was 24 steam. According to [6], the high number of productive tillers at the variety of IR 64 (without Sub-1 gene) was caused of the small percentage of live plants or some was not live at this variety that caused the steams goodly grow, there were so many tillers because of enough space to get the shine, water, and elements, and at the last will increase number of productive tillers per steam.

The research result of [1] showed that variety of IR 64 that experienced the submersion gripping, there were so many died steams, yet the live steams made the growth of the plants very good with the high number of productive tillers, rather than the plants that were not submerged.

Table 4.Number of productive tillers of two varieties of rice at some treatments of fertilizing in the condition of submersion gripping at lowland swamp

\begin{tabular}{lllllllllll}
\hline \multirow{2}{*}{ Vari } & \multicolumn{4}{c}{ Shallow-back swamp } & \multicolumn{5}{c}{ Middle-back swamp } \\
\cline { 2 - 10 } eties & P0 & P1 & P2 & P3 & P4 & P0 & P1 & P2 & P3 & P4 \\
\hline Inpara 5 & 13.2 & 9.2 & 12.0 & 10.6 & 10.4 & 20 & 14 & 23 & 15 & 15 \\
IR 64 & 13.8 & 9.6 & 12.4 & 12.9 & 10.6 & 19 & 22 & 24 & 20 & 19 \\
\hline
\end{tabular}

Notes: P0: Basic fertilizing without submersion, P1: Basic fertilizing, P2: Fertilizing before being submerged, P3: Fertilizing after being submerged, P4: Fertilizing before and after being submerged

The research result of [1] showed that variety of IR 64 that experienced the submersion gripping, there were so many died steams, yet the live steamrs made the growth of the plants very good with the high number of productive tillers, rather than the plants that were not submerged.

\subsection{Plant dry matter weight}

Plant dry matter weight with two varieties of rice tends to increase by the extending of fertilizing treatment before and/or after being submerged whether in the shallow-back swamp or in the middle-back swamp (Table 4).
The variety of IR 64 (V2) that was given the fertilizing treatment had the highest plant dry matter weight that was $33 \mathrm{~g}$ per clump the shallow-back swamp meanwhile at the middle-back swamp, the variety of Inpara 5 (V1) that was given the fertilizing treatment before being submerged had the highest weight that was $55.8 \mathrm{~g}$ per clump. This was caused of both varieties tends to have number of productive tillers and plant height that treatment, so that it affected plant dry matter weight high.

\section{Table 4.Plant dry matter weight $(\mathrm{g})$ of two varieties of rice at some fertilizing treatments in the condition of submersion gripping at lowland swamp}

\begin{tabular}{lllllllllll}
\hline \multirow{2}{*}{ Vari } & \multicolumn{3}{c}{ Shallow-back swamp } & \multicolumn{8}{c}{ Middle-back swamp } \\
\cline { 2 - 11 } & P0 & P1 & P2 & P3 & P4 & P0 & P1 & P2 & P3 & P4 \\
\hline Inpara 5 & 29 & 14 & 20 & 16 & 16 & 27.6 & 38 & 55.8 & 30.6 & 40.8 \\
IR 64 & 37 & 19 & 24 & 33 & 24 & 29.8 & 37.9 & 42.1 & 37.3 & 33.5
\end{tabular}

Notes:P0: Basic fertilizing without submersion, P1: Basic fertilizing, P2: Fertilizing before being submerged, P3: Fertilizing after being submerged, P4: Fertilizing before and after being submerged.

\subsection{Yield and yield components}

The Yield and yield components of rice indicated various responds at two varieties of rice by fertilizing treatment before and/or after being submerged whether at the shallow-back swamp or at the middle-back swamp ( Table 6 and Table 7). The variety of Inpara 5 (V2) with the 
extending of fertilizing treatment before being submerged (P2) had the highest yield of rice, that was 2.9 ton ha $^{-1}$ at the shallow-back swamp or experienced the decreasing of result $16 \%$ toward without submersion and 5.1 ton ha ${ }^{-1}$ at the shallow-back swamp or experienced the decreasing of result $6 \%$ toward without submersion . Besides, some yield components at two varieties of rice tend to increase with the fertilizing treatment before and/or after being submerged whether at the shallow-back swamp or at the middle-back swamp, yet the result of rice produced at every variety for each hectare was determined by the percentage of survive plants varieties. This was caused of the high result of Inpara 5 rice variety for the both types of swamp field because of the percentage of survive plants was $92 \%$ for the shallowback swamp and $97 \%$ for middle-back swamp, so that the population per wide unit became higher. According to [8], the potential of result was determined by the prediction of all result components per clump was timed of the amount of population per hectare and the percentage of survive plants.

Table.6: The Yield with two varieties of rice per hectare (ton) at some fertilizing treatments to the condition of submersion gripping at lowland swamp

\begin{tabular}{lllllllllll}
\hline \multirow{2}{*}{ Vari } & \multicolumn{4}{c}{ Shallow-back swamp } & \multicolumn{5}{c}{ Middle-back swamp } \\
\cline { 2 - 12 } eties & P0 & P1 & P2 & P3 & P4 & P0 & P1 & P2 & P3 & P4 \\
\hline Inpara 5 & 3.4 & 2.4 & 2.9 & 2.2 & 2.4 & 5.4 & 2.9 & 5.1 & 4.5 & 4.0 \\
IR 64 & 3.4 & 2.1 & 2.4 & 2.3 & 2.0 & 5.8 & 1.8 & 5.0 & 5.2 & 3.7 \\
\hline
\end{tabular}

Notes: P0 : Basic fertilizing without submersion, P1: Basic fertilizing, P2: Fertilizing before being submerged, P3: Fertilizing after being submerged, P4: Fertilizing before and after being submerged.

Table 7. The influence of fertilizing and varieties toward some component result at various lowland swamp

\begin{tabular}{lcccccc}
\hline \multirow{2}{*}{ Treat } & \multicolumn{3}{c}{ Shallow-back swamp } & \multicolumn{3}{c}{ Middle-back swamp } \\
\cline { 2 - 7 } ment & 1 & 2 & 3 & 1 & 2 & 3 \\
\hline V1P0 & 170.0 & 82.5 & 2.6 & 173.4 & 83 & 2.3 \\
V2P0 & 132.0 & 79.2 & 2.3 & 164.5 & 77 & 2.6 \\
V1PI & 140.8 & 77.6 & 2.2 & 140.3 & 76 & 2.4 \\
V2P1 & 147.9 & 54.9 & 2.4 & 132.1 & 73 & 2.2 \\
V1P2 & 148.0 & 79.3 & 2.4 & 176.3 & 82 & 2.5 \\
V2P2 & 155.9 & 78.4 & 2.2 & 163.6 & 81 & 2.3 \\
V1P3 & 155.3 & 80.6 & 2.3 & 143.6 & 79 & 2.2 \\
V2P3 & 150.0 & 79.7 & 2.2 & 156.3 & 75 & 2.3 \\
V1P4 & 135.5 & 75.3 & 2.1 & 154.0 & 77 & 2.3 \\
V2P4 & 127.8 & 76.2 & 2.1 & 161.8 & 75 & 2.4 \\
\hline
\end{tabular}

Notes: 1 = Number of grains per panicle (grains), $2=$ Percentage of filled grains per panicle (\%), and $3=100$ grains weight (g). V1: Inpara 5, 2: IR 64, P0: without submersion, P1: basic fertilizing, P2: fertilizing before being submerged, P3: fertilizing after being submerged, P4: Fertilizing before and after being submerged.

\section{CONCLUSIONS}

Fertilization treatment can increase rice production growth and submergence stress conditions, varieties of Inpara 5 added with fertilization before flooded can suppress a decrease in grain yield for $16 \%$ in the shallowback swamp and $6 \%$ in middle-back swamps or with each production of 2.9 and 5.1 tons per hectare, varieties of Inpara 5 which is giving fertilization before flooded, tends to be a good treatment to be developed in rice submergence cultivation both in the shallow-back swamp and middle-back swamps.

\section{ACKNOWLEDGMENTS}

We especially wish to acknowledge the Ministry of Research, Technology and Higher Education that had already provided funding for this research through Competitive Research Grant (Hibah Bersaing) for fiscal year of 2015 .

\section{REFERENCES}

[1] A.K. Makarim, E. Suhartatik, G.R. Pratiwi and Ikhwani, 2009 A Final Report of ROPP DIPA 2009. Indonesian Rice Research Institute. Indonesian Agricultural Research and Development. 
[2] Badan Perencanaan Pembangunan Nasional. 2010 Indonesia Climate Change Sectoral Roadmap (ICCSR) of Agrcultural Sector. http://bappenas.go.id

[3] CGIAR, 2006 Consultative Group on International Agriculture Research.

http://www.cgiar.org/web-archives/www-cgiar-orgnewsroom-releases-news-asp-idnews-501/. Accessed on September 24, 2012.

[4] E.M. Septiningsih, A.M. Pamplona, D.L. Sanches, C.N. Neeraja, G.V. Vergara, S. Heuer, A.M. Ismail and D.J. Mackill. 2009 Ann. Bot.. vol. 103(2), pp. 151-160. doi: 10.1093/aob/mcn206 9)

[5] Gribaldi, R.A. Suwignyo, M. Hasmeda and R. Hayati, 2014 Jurnal Agronomi Indonesia, vol. 42(1), pp. 17-23.

[6] _, 2016 International. Journal of Agrivita, vol. 38(1), pp. 64-72.

[7] IRRI and the Research and Development Council of Food Crops, 2009 Food Crops Research and Development Center.

[8] I. Khairullah, 2006 Sinar Tani Edisi 8 -14 Nopember 2006.

[9] M.I. Naning, D.M. Bernas, D. P. Sulistiyawah and S. Nurul, 2008 Proceedings of the Annual Meeting of the Scientific Association of Indonesian soil science, Palembang . Desember 17-18, 2008.

[10] Ngudiantoro, 2010 Jurnal Penelitian Sains, vol. 13(3), pp. 12-18.

[11] R.A. Suwignyo, F. Zulvica and Hendryansyah, 2008 The 3rd National Seminar on Rice Day. Indonesian Rice Research Institute, Sukamandi. July 22-24, 2008.

[12]R.A. Suwignyo, A. Wijaya, H. Sihombing and Gribaldi, 2012 Jurnal Lahan Suboptimal, vol. 1(1), pp. 1-11.

[13] Waluyo, Suparwoto and Sudaryanto, 2008 Jurnal Hidrosfir Indonesia, vol. 3(2), pp. 57-66. 